Folia Cardiologica 2017 tom 12 , nr 4, strony 362-370 DOI: 10.5603/FC.2017.0069 Copyright @ 2017 Via Medica ISSN 2353-7752

\title{
Znaczenie rokownicze wybranych parametrów echokardiograficznych w ciężkiej skurczowej niewydolności serca
}

\section{Prognostic significance of selected echocardiographic parameters in severe systolic heart failure}

\author{
Wojciech Gilewski, Władysław Sinkiewicz \\ II Katedra Kardiologii Collegium Medicum w Bydgoszczy, \\ Uniwersytet Mikołaja Koperniaka w Toruniu
}

\section{Streszczenie}

Echokardiografia ma ugruntowane miejsce w diagnostyce kardiologicznej. Dzięki możliwości oceny budowy i funkcji serca jest niezastąpiona przy ustalaniu rozpoznania niewydolności serca (HF), w diagnostyce różnicowej jej przyczyn, a także w prognozowaniu jej przebiegu. Powiększenie wymiarów lewej komory oraz obniżenie jej frakcji wyrzutowej, charakterystyczne dla zastoinowej HF, wykorzystano w najczęściej stosowanych skalach rokowniczych. Prawdopodobnie jednak w grupie chorych z najcięższym uszkodzeniem lewej komory większe znaczenie rokownicze mają powikłania hemodynamiczne tego stanu. Należą do nich: wzmożone ciśnienie napełniania lewej komory, którego konsekwencją jest nadciśnienie płucne, przeciążenie ciśnieniowe i objętościowe prawej komory i jej wtórna dysfunkcja skurczowa. Zarówno klasyczne, jak i nowoczesne parametry echokardiograficzne uzyskują coraz większe znaczenie w prognozowaniu przebiegu HF z obniżoną frakcją wyrzutową.

Słowa kluczowe: echokardiografia, rokowanie, przewlekła niewydolność serca

Folia Cardiologica 2017; 12, 4: 362-370

\section{Wstęp}

Niewydolność serca (HF, heart failure) została zdefiniowana według Europejskiego Towarzystwa Kardiologicznego jako zespół chorobowy, w którym u chorego występują typowe objawy podmiotowe oraz przedmiotowe wynikające z nieprawidłowości budowy i/lub czynności serca, które wpływają na zmniejszenie rzutu serca i/lub podwyższone wartości ciśnień wewnątrzsercowych [1]. Podstawowy podział patofizjologiczny HF jest związany ze stopniem upośledzenia funkcji skurczowej lewej komory (LV, left ventricle) serca. Najbardziej uznanym parametrem wykorzystywanym do oceny zaawansowania globalnej dysfunkcji skurczowej lewej komory jest jej frakcja wyrzutowa (LVEF, left ventricular ejection fraction). Według obecnej nomenklatury termin $\mathrm{HF}$ z obniżoną frakcją wyrzutową (HFrEF, heart failure with reduced ejection fraction) dotyczy chorych z EF poniżej 35\%.

W krajach rozwiniętych u około 1-3\% dorosłej populacji występuje HF, przy czym u przynajmniej połowy pacjentów obciążonych HF stwierdza się HFrEF. Niewydolność serca jest obecnie jednym z najpoważniejszych problemów zdrowotnych w krajach rozwiniętych. Pięcioletnia śmiertelność w jej przebiegu nadal jest zbliżona do występującej w chorobie nowotworowej i osiągnęła w badaniu Rotterdam 41\% [2].

Adres do korespondencji: dr n. med. Wojciech Gilewski, II Katedra Kardiologii Collegium Medicum, Szpital Uniwersytecki nr 2 im. dr. J. Biziela, ul. Ujejskiego 75, 85-168 Bydgoszcz, e-mail: wgilewski@wp.pl 
Dotychczas odkryto wiele różnych parametrów prognostycznych służących do oceny rokowania w HF. Do klasycznych należą dane z wywiadu, takie jak: wiek, płeć i klasa czynnościowa według New York Heart Association (NYHA) oraz choroby współistniejące: cukrzyca, choroba niedokrwienna serca, przewlekła choroba nerek, depresja i przewlekła choroba płuc. 0 niekorzystnym rokowaniu świadczą również dane z badania przedmiotowego: niskie ciśnienie skurczowe, podwyższona częstotliwość rytmu serca, migotanie przedsionków, cechy zastoju w krążeniu płucnym, słyszalny trzeci ton nad sercem oraz wyniki niektórych badań laboratoryjnych, na przykład podwyższone stężenie peptydu natriuretycznego typu B.

Echokardiografia należy do najczęściej wykonywanych badań obrazowych wykorzystywanych do oceny budowy i funkcji serca. Dostarcza ona informacji o możliwej etiologii HF, jej ciężkości oraz rokowaniu, pozwalając na ustalenie trafnego rozpoznania, planowanie obserwacji i leczenia [1]. Z patofizjologicznego punktu widzenia odrębnej oceny wymagają: budowa i funkcja skurczowa LV, jej funkcja rozkurczowa z pomiarem niedomykalności mitralnej i wielkości lewego przedsionka oraz wielkość i funkcja prawej komory ( $\mathrm{RV}$, right ventricle) z oszacowaniem nadciśnienia płucnego i wolemii, w tym z oceną prawego przedsionka i żyły głównej dolnej. Wciąż poszukuje się nowych parametrów echokardiograficznych, które mogłyby wiarygodnie przewidywać rokowanie w tej grupie chorych. Kliniczne zastosowanie danych z poniżej przedstawionych badań utrudniają: niejednorodność grup badanych pacjentów pod względem liczebności i ciężkości HF, różne punkty końcowe prowadzonych badań i ich interpretacja statystyczna (tab. 1) [3-23].

\section{Wymiary lewej komory i jej funkcja skurczowa}

Zarówno wymiary LV, jej objętości, jak i EF są uznanymi parametrami prognostycznymi [5]. Patologiczna przebudowa LV pod postacią ekscentrycznego przerostu ze wzrostem wskaźnika jej masy i rozstrzeni zdefiniowanej jako niska względna grubość ściany, RWT poniżej 0,34 (relative wall thickness) okazała się również niekorzystnym czynnikiem rokowniczym w badaniu Dini i wsp. [24]. Wiele modeli rokowniczych uwzględnia EF jako ważną składową analiz wieloczynnikowych. Jednakże w większości przypadków nie oceniano wpływu wartości EF w jednolitej grupie chorych z ciężką dysfunkcją skurczową LV, tj. EF poniżej 35\%. Najczęściej obejmowały one duże grupy pacjentów, którzy charakteryzowali się znacznym odchyleniem standardowym od wartości średnich EF. Na przykład badanie SFHM (Seattle Heart Failure Model) obejmowało 6 kohort, w których średnie EF wynosiły od $21 \pm 6 \%$ do $35 \pm 11 \%$ z zakresem 10-75\% [5]. W badaniu Spinar i wsp. [7], u których 85\% grupy badanej mieściło się w przedziale EF między 20-40\%, nie stwierdzono istotnego wpływu EF na rokowanie. Dokład- niejszym, mniej zależnym od badacza i przez to bardziej obiektywnym parametrem oceny funkcji skurczowej LV jest globalne skurczowe odkształcenie podłużne (GLS, global longitudinal strain). Wymaga jednak zastosowania nowoczesnej metody śledzenia markerów akustycznych (speckle tracking). Wartości charakteryzujące ludzi zdrowych wynoszą poniżej-20\% (wartości ujemne). W badaniu Sengeløv i wsp. [8] spośród licznych konwencjonalnych parametrów echokardiograficznych był to jedyny wykładnik złego rokowania niezależny od wieku, płci, etiologii, ciśnienia tętniczego, częstotliwości rytmu serca, przebytych rewaskularyzacji i chorób współistniejących. Pogorszenie GLS o $1 \%$ zwiększało śmiertelność całkowitą o około $20 \%$ wśród chorych z rytmem zatokowym.

W badaniu własnym autora [25] grupa chorych z ciężką skurczową HF podczas kwalifikacji do elektywnego przeszczepu serca była dosyć jednorodna pod względem stopnia dysfunkcji skurczowej LV: ponad $72 \%$ chorych miało EF w wąskim zakresie - 20-30\% (średnia EF 22,7\% $\pm 5,3$ ). Podczas rocznej obserwacji wymiary LV ani EF nie miały wpływu na osiągnięcie złożonego punktu końcowego (zgon lub hospitalizacja z powodu zaostrzenia HF) podczas rocznej obserwacji (tab. 2).

\section{Funkcja rozkurczowa lewej komory, niedomykalność mitralna i lewy przedsionek}

Dysfunkcja rozkurczowa jest uważana za patologię poprzedzającą wystąpienie HF-REF, a następnie nasilającą się wraz z jej naturalnym przebiegiem. Wiąże się to głównie ze wzmożonym ciśnieniem napełniania LV, które jest odpowiedzialne za większość powikłań hemodynamicznych tej jednostki chorobowej. Czas deceleracji wczesnej fali napływu mitralnego DT (deceleration time) poniżej $130 \mathrm{~ms}$ okazał się niezależnym czynnikiem złego rokowania w badaniu Morales i wsp. [13]. Wskaźnik E/e', będący ilorazem prędkości wczesnej fali napływu mitralnego i wczesnorozkurczowej prędkości pierścienia mitralnego mierzonego za pomocą echokardiografii doplerowskiej (TDI, tissue Doppler imaging), jest uważany za najlepszy parametr charakteryzujący ciśnienie napełniania LV. Wartości E/e' przekraczające 15 świadczą o złym rokowaniu chorych zarówno z niską, jak i zachowaną EF $[12,26]$. Ciężka funkcjonalna niedomykalność zastawki mitralnej może powstawać na skutek złożonych mechanizmów patologicznych: poszerzenia pierścienia zastawki, przemieszczenia mięśni brodawkowatych czy retrakcji płatków wtórnych do dysfunkcji skurczowej i/lub rozkurczowej LV. Udowodniono, że powstanie tej wady prowadzi do gorszego przebiegu klinicznego HF i zwiększonej śmiertelności [14]. Wtórnie do niedomykalności mitralnej i wzmożonego ciśnienia napełniania dochodzi do rozstrzeni lewego przedsionka. Indeksowany wymiar lewego przedsionka okazał się najlepszym parametrem echokardiograficznym 
Tabela 1. Zbiorcze przedstawienie parametrów echokardiograficznych i ich wartość prognostyczna

\begin{tabular}{|c|c|c|c|c|c|c|}
\hline Parametr & $\begin{array}{l}\text { Wartości } \\
\text { referencyjne [3] }\end{array}$ & Autor i data publikacji & $\begin{array}{l}\text { Badana } \\
\text { grupa }\end{array}$ & Punkt odcięcia & Wartość prognostyczna & $\begin{array}{l}\text { Punkty } \\
\text { końcowe }\end{array}$ \\
\hline $\begin{array}{l}\text { LVDd } \\
\text { (ryc. 1A) }\end{array}$ & $37,8-58,4 \mathrm{~mm}$ & Meluzín 2003 [4] & 139 & $>70 \mathrm{~mm}$ & MHR 1,06 & $\mathrm{CD}, \mathrm{EH}, \mathrm{ICD}$ \\
\hline \multirow[t]{3}{*}{$\begin{array}{l}\text { EF } \\
\text { (ryc. 1B) }\end{array}$} & \multirow[t]{3}{*}{$52-74 \mathrm{~mm}$} & Levy 2006 [5] & 1125 & $21 \pm 6$ & $\begin{array}{l}\text { UHR } 0,971 \\
\text { MHR } 1,023 \text { dla } 100 / \text { EF }\end{array}$ & $\begin{array}{l}D \\
D\end{array}$ \\
\hline & & Madsen 1994 [6] & 190 & $\begin{array}{l}\text { Jako zmienna } \\
\text { ciągła (media- } \\
\text { na 30\%) }\end{array}$ & $\mathrm{MHR}$ In EF 3,19 & $\mathrm{CD}, \mathrm{OHT}, \mathrm{EH}$ \\
\hline & & Spinar 1996 [7] & 300 & $30,9 \pm 7,8 \%$ & NS & $\mathrm{D}$ \\
\hline GLS & $<(-20 \%)$ & Sengeløv 2015 [8] & 1065 & & $\begin{array}{l}\text { MHR 1,22 na 1\% obni- } \\
\text { żenia }\end{array}$ & $\mathrm{D}$ \\
\hline $\begin{array}{l}\text { LAl } \\
\text { (ryc. 1C) }\end{array}$ & $\mathrm{BD}$ & Acarturk 2008 [9] & 75 & & $\begin{array}{l}\text { OR } 1,383 \text { na wzrost } \\
1 \mathrm{~mm} / \mathrm{m}^{2}\end{array}$ & $\mathrm{CD}+\mathrm{EH}$ \\
\hline $\begin{array}{l}\text { LAarea } \\
\text { (ryc. 1D) }\end{array}$ & $\mathrm{BD}$ & Giannuzzi 1996 [10] & 508 & $>18 \mathrm{~cm}^{2}$ & RR 1,73 & $\mathrm{CD}, \mathrm{EH}$ \\
\hline LAVI & $16-34 \mathrm{ml} / \mathrm{m}^{2}$ & Rossi 2007 [11] & 273 & $>63 \mathrm{ml} / \mathrm{m}^{2}$ & MHR 1,07 & $\mathrm{CD}, \mathrm{OHT}, \mathrm{EH}$ \\
\hline $\begin{array}{l}E / e^{\prime} \\
\text { (ryc 2A, B) }\end{array}$ & $\begin{array}{l}<8 \mathrm{~cm} / \mathrm{s}^{*} \\
>15 \mathrm{~cm} / \mathrm{s} !\end{array}$ & Rossi 2011 [12] & 49 & 15 & MHR 1,36 wzrost o $3 \mathrm{j}$. & $\mathrm{D}+\mathrm{OHT}$ \\
\hline \multirow[t]{2}{*}{$\begin{array}{l}\text { DT } \\
\text { (ryc. 2A) }\end{array}$} & \multirow{2}{*}{$\begin{array}{l}142 \pm 19 \mathrm{~ms} \\
\text { (od } 16 \text { rż.) } \\
200 \pm 29 \mathrm{~ms} \\
\text { (> } 60 \text { rż.) }\end{array}$} & Morales 2002 [13] & 60 & $<130 \mathrm{~ms}$ & $\begin{array}{l}44 \% \text { v. } 80-83 \% \\
\text { (porównanie tercyli)/ } \\
/ 21 \pm 6 \text { mies. }\end{array}$ & $\mathrm{CD}, \mathrm{OHT}, \mathrm{EH}$ \\
\hline & & Giannuzzi 1996 [10] & 508 & $<125 \mathrm{~ms}$ & RR 1,93 & $\mathrm{CD}, \mathrm{EH}$ \\
\hline $\begin{array}{l}\text { MR } \\
\text { (ryc. 2C) }\end{array}$ & - & Okura 2008 [14] & 524 & $\begin{array}{l}\text { Obecność cięż- } \\
\text { kiej MR }\end{array}$ & RR 2,34 & $\mathrm{D} ; \mathrm{HF}$ \\
\hline $\begin{array}{l}\text { RVID2 } \\
\text { (ryc. 3A) }\end{array}$ & $19-35$ & Maekawa 2011 [15] & 122 & $\begin{array}{l}\text { Między ter- } \\
\text { cylami }<32 \\
\text { i }>39 \mathrm{~mm}\end{array}$ & UHR 1,036 & $\mathrm{CD}$ \\
\hline $\begin{array}{l}\text { RVarea/ } \\
\text { /LVarea }\end{array}$ & - & Sun 1997 [16] & 100 & $>0,5$ & $\mathrm{RR} 4,4$ & $\mathrm{D}$ \\
\hline $\begin{array}{l}\text { TAPSE } \\
\text { (ryc. 3C) }\end{array}$ & $\begin{array}{l}24 \pm 3,5 \\
<17 \mathrm{~mm} !\end{array}$ & $\begin{array}{l}\text { Ghio } 2000 \text { [17] } \\
\text { Vizzardi } 2012 \text { [18] }\end{array}$ & $\begin{array}{l}140 \\
95\end{array}$ & $\begin{array}{l}<14 \mathrm{~mm} \\
<18 \mathrm{~mm}\end{array}$ & $\begin{array}{l}\text { MHR 2,58 } \\
\text { MHR 0,42 }\end{array}$ & $\begin{array}{l}\mathrm{OHT}, \mathrm{CD} \\
\mathrm{CD}, \mathrm{EH}\end{array}$ \\
\hline RAareal & $\begin{array}{l}21-25 \pm 6-7 \\
\mathrm{ml} / \mathrm{m}^{2}\end{array}$ & Hinderliter 2008 [19] & 211 & & $\begin{array}{l}\text { MHR 1,41 dla wzrostu } \\
\text { o } 20 \mathrm{ml} / \mathrm{m}^{2}\end{array}$ & D \\
\hline $\begin{array}{l}\text { S'TV } \\
\text { (ryc. 3D) }\end{array}$ & $\begin{array}{l}14,1 \pm 2,3 \\
<9,5 !\end{array}$ & $\begin{array}{l}\text { Meluzín } 2003 \text { [4] } \\
\text { Damy } 2009 \text { [20] }\end{array}$ & $\begin{array}{l}139 \\
136\end{array}$ & $\begin{array}{l}<10,8 \mathrm{~cm} / \mathrm{s} \\
<9,5 \mathrm{~cm} / \mathrm{s}\end{array}$ & $\begin{array}{l}\text { MHR 0,85 } \\
\text { MHR 8,83 }\end{array}$ & $\begin{array}{l}\text { CD, EH, ICD } \\
\text { D, OHT, EH, } \\
\text { VAD }\end{array}$ \\
\hline $\begin{array}{l}\text { IVC } \\
\text { (ryc. 3B) }\end{array}$ & $<2,1 \mathrm{~cm}$ & Pellicori 2013 [21] & 568 & $\begin{array}{l}\text { Między ter- } \\
\text { cylami }<18 \\
\mathrm{i}>22 \mathrm{~mm}\end{array}$ & MHR 1,13 & $\mathrm{CD}, \mathrm{EH}$ \\
\hline $\begin{array}{l}\text { TRPG } \\
\text { (ryc. 2D) }\end{array}$ & - & $\begin{array}{l}\text { Kjaergaard } 2007 \\
{[22]}\end{array}$ & 388 & & MHR 1,09 na 5 mm Hg & $\mathrm{D}$ \\
\hline $\begin{array}{l}\text { TRPG/ } \\
\text { /TAPSE }\end{array}$ & $\mathrm{BD}$ & Guazzi 2013 [23] & 247 & $\begin{array}{l}36 \mathrm{~mm} \mathrm{Hg} / \\
/ \mathrm{mm}\end{array}$ & MHR 10,3 & $\mathrm{D}$ \\
\hline
\end{tabular}

LVDd (left ventricular diastolic diameter) - rozkurczowy wymiar lewej komory; MHR (multivariate hazard ratio) - hazard względny w analizie wieloczynnikowej; CD (cardiac death) - śmierć sercowa; EH (emergency hospitalization) - pilna hospitalizacja; NS - nieistotne statystycznie; ICD (implantable cardioverter-defibrillator) - implantacja wszczepialnego kardiowertera-defibrylatora; EF (ejection fraction) - frakcja wyrzutowa; UHR (unvariate hazard ratio) - hazard względny w analizie jednoczynnikowej; D, VAD - implantacja urządzenia wspomagającego serce; OHT (orthotopic heart transplantation) przeszczepienie serca; GLS (global longitudinal strain) - globalne odkształcenie podłużne; LAl (left atrial index) - indeksowany wymiar lewego przedsionka; BD - brak danych; OR (odds ratio) - iloraz szans; LAarea (left atrial area) - pole lewego przedsionka; LAVI (left atrial volume index) - indeksowana objętość lewego przedsionka; E/e' - iloraz prędkości wczesnego napływu mitralnego i ruchu pierścienia mitralnego; DT (deteleration time) - czas deceleracji fali wczesnego napływu mitralnego; RR (relative risk) - ryzyko względne; MR (mitral regurgitation) - obecność niedomykalności mitralnej; RVID2 (right ventricular internal diastolic diameter) - rozkurczowy wymiar prawej komory w jej części środkowej; RVarea/LVarea - iloraz pola powierzchni (area) prawej (RV, right ventricle) i lewej komory (left ventricle); TAPSE (tricuspid annular plane systolic excursion) - skurczowy ruch pierścienia trójdzielnego; RAareal (left atrial area index) - indeksowane pole prawego przedsionka; S'TV - prędkość skurczowa (S') pierścienia trójdzielnego (tricuspid valve) ; IVC (inferior vena cava) - maksymalna średnica żyły głównej dolnej; TRPG (transtricuspid pressure gradient) - maksymalny gradient przez zastawkę trójdzielną; TRPG/TAPSE - iloraz TRPG i TAPSE 


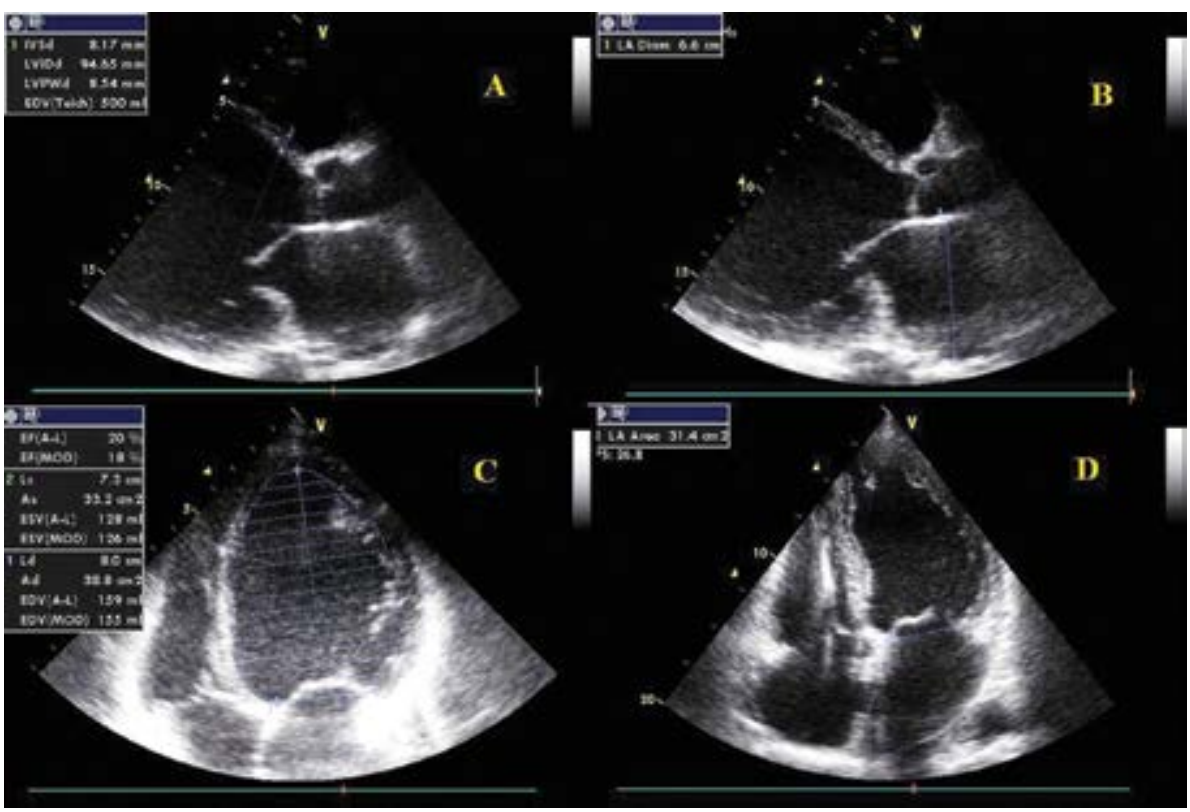

Rycina 1A-D. Projekcja przymostkowa w osi długiej (A, B) i koniuszkowa czterojamowa (C, D): A. Wymiar końcoworozkurczowy lewej komory; B. Wymiar lewego przedsionka; C. Pomiar frakcji wyrzutowej metodą Simpsona z oceną objętości końcoworozkurczowej (zwraca uwagę sferyczność lewej komory); D. Pole powierzchni lewego przedsionka

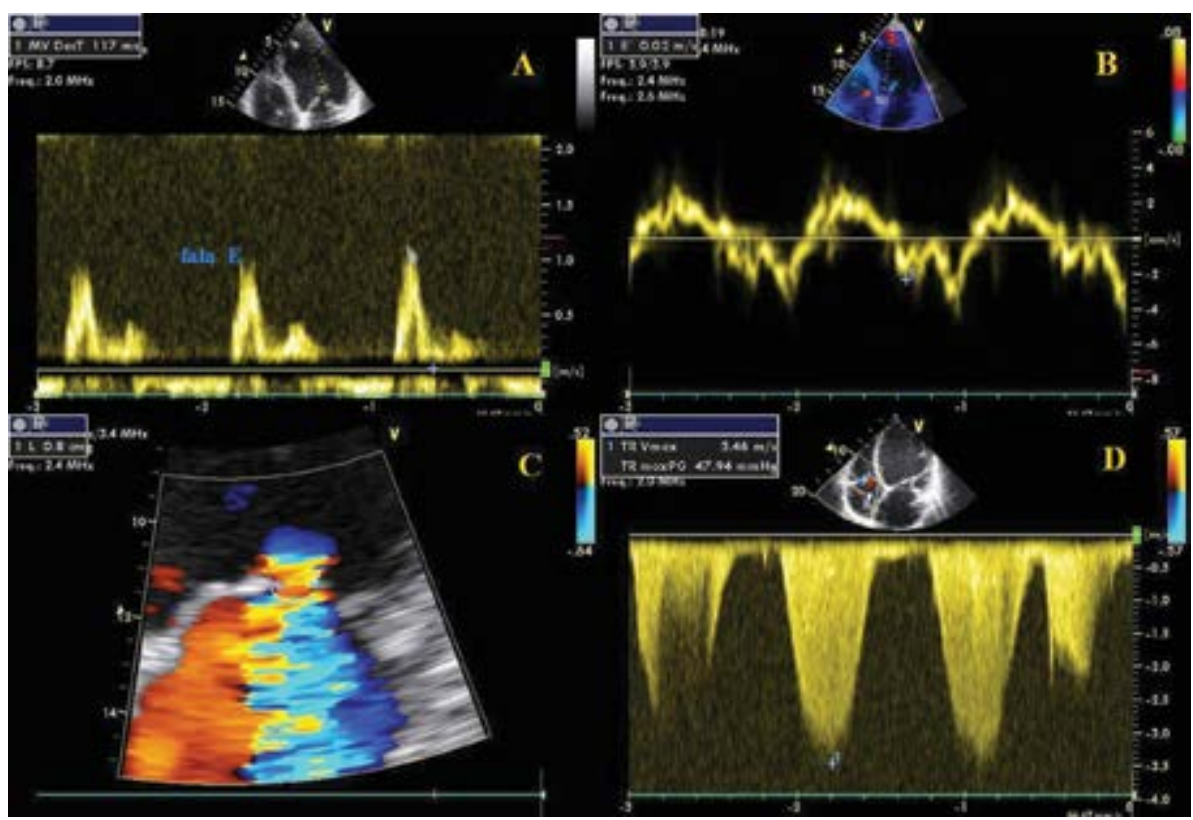

Rycina 2A-D. Projekcja koniuszkowa czterojamowa: A. Spektrum prędkości napływu mitralnego z zaznaczonym czasem deceleracji i wczesną falą napływu mitralnego E; B. Dopler tkankowy z zaznaczoną falą e'; C. Szeroka fala zwrotna mitralna z talią 8 mm; D. Spektrum prędkości niedomykalności trójdzielnej z oceną gradientu skurczowego przez zastawkę

ograniczenia tolerancji wysiłku i wystąpienia zgonu lub pilnej hospitalizacji w badaniu Acarturka i wsp. [9]. Pole powierzchni lewego przedsionka wymagające obrysu jego ścian również wnosi dodatkowe informacje prognostyczne u chorych z niską EF [10]. Najdokładniejszy jest pomiar ob- jętości lewego przedsionka, zwłaszcza gdy indeksuje się go względem pola powierzchni ciała pacjenta. Jego znaczenie prognostyczne wykazano w wielu badaniach u chorych z HF. W badaniu Rossi i wsp. [11] wielkością graniczną było 63 $\mathrm{ml} / \mathrm{m}^{2}$ powierzchni ciała. 


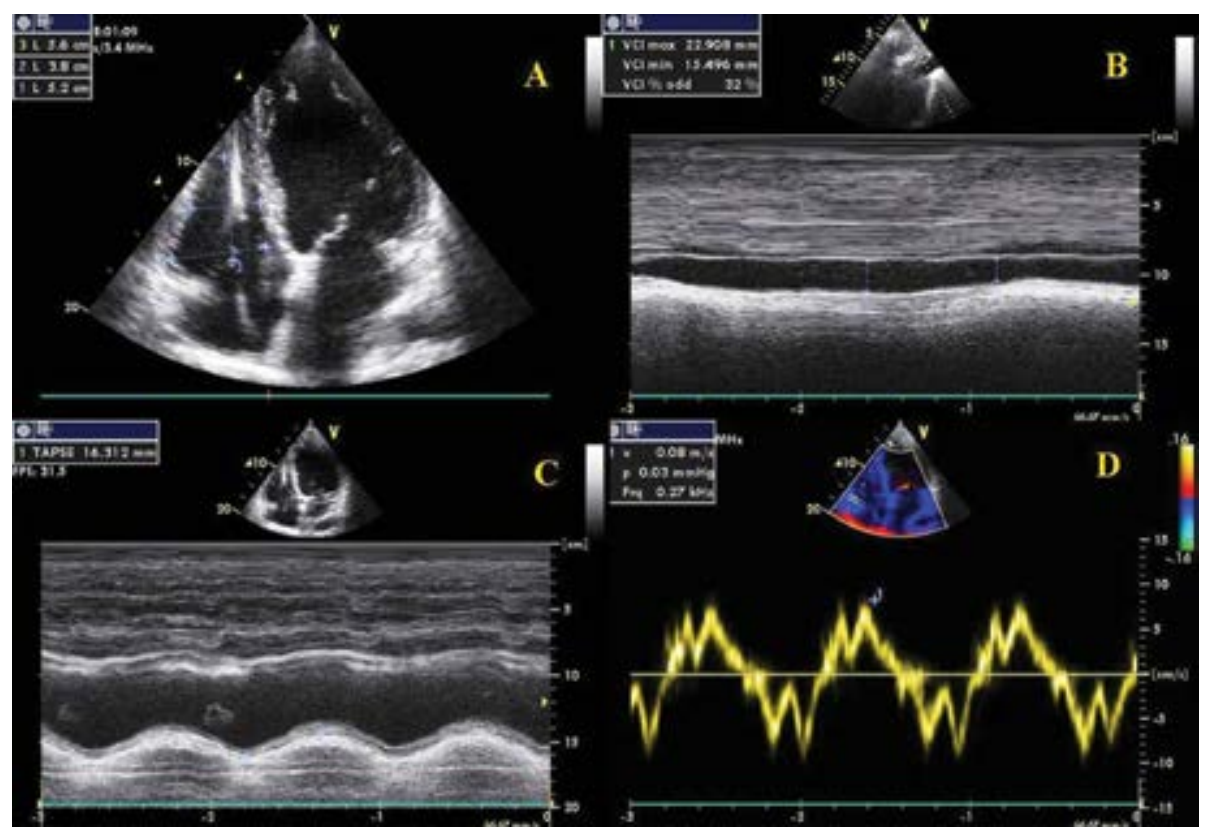

Rycina 3A-D. Projekcja koniuszkowa czterojamowa zorientowana na prawe jamy serca (A, C, D) i podmostkowa (B): A. Wymiary rozkurczowe prawej komory; B. Wymiary żyły głównej dolnej na wdechu i wydechu; C. TAPSE (w prezentacji M-mode); D. S'TV (dopler tkankowy metodą pulsacyjną)

\section{Funkcja prawej komory i nadciśnienie płucne}

Echokardiograficzna ocena RV sprawia znaczne trudności z uwagi na jej złożoną budowę anatomiczną. Najnowsze wytyczne amerykańskich i europejskich towarzystw echokardiograficznych [27] zalecają wykonanie aż pięciu pomiarów wewnętrznych RV: dwóch części odpływowej (proksymalny i dystalny) oraz trzech drogi napływu (dwóch poprzecznych i podłużnego). W badaniu Maekawa i wsp. [15] podkreślono znaczenie prognostyczne wymiaru środkowego poprzecznego RV przy przyjęciu i wypisie chorego z zaostrzeniem przewlekłej HF. W badaniu Sachero i wsp. wymiar końcowo-rozkurczowy RV był jedynym, który w analizie wieloczynnikowej okazał się istotnie wpływać na śmiertelność w grupie chorych z kardiomiopatią rozstrzeniową [3]. W badaniu Sun i wsp. [16] w podobnej grupie chorych oceniano wielkość RV za pomocą jej pola powierzchni względem pola LV. Stwierdzono, że pacjenci z powiększeniem RV mają prawie 3-krotnie większą śmiertelność w ciągu 4 lat obserwacji, niż chorzy bez istotnego jej powiększenia. Ze względu na złożoną budowę przestrzenną i bogate beleczkowanie RV rzadko oblicza się jej EF za pomocą echokardiografii. Ekwiwalentem RVEF jest jej frakcjonowana zmiana powierzchni (FAC, fractional area change). Obecnie bardzo często używa się parametru odzwierciedlającego funkcję skurczową włókien podłużnych RV, który polega na pomiarze amplitudy ruchu pierścienia zastawki trójdzielnej (TAPSE, tricuspid annular plane systolic excursion). Już w 1984 roku w bada- niu Kaula i wsp. [28] stwierdzono wysoką korelację TAPSE (wyższą w porównaniu z FAC) z frakcją wyrzutową prawej komory (RVEF, right vetricular ejection fraction) uzyskana za pomocą metod radioizotopowych. Analiza Ghio i wsp. z 2000 roku uwzględniała wiele czynników klinicznych i echokardiograficznych u 140 chorych z ciężką skurczową HF (EF < 35\%) w III i IV klasie według NYHA. W ciągu średnio 2 lat obserwacji prawie 1/3 chorych zmarła, a 7 osobom wykonano pilną transplantację serca. W analizie wieloczynnikowej dla całej grupy badanej tylko TAPSE z punktem odcięcia dla wartości mniejszej lub równej 14 mm (współczynnik ryzyka [HR, hazard ratio] $=2,58$ ) i przynależność do klasy III lub IV według NYHA miały znaczenie przy ocenie rokowania [17]. W badaniu Vizzardiego i wsp. [18] w grupie pacjentów o lepszej funkcji skurczowej LV (EF < 40\%) i mniej obciążonym rokowaniu (śmiertelność 5-letnia 24\%) wartość progowa TAPSE wynosiła $18 \mathrm{~mm}$. Nowszym parametrem wykorzystującym TDI jest skurczowa prędkość pierścienia zastawki trójdzielnej zależna od kurczliwości wolnej ściany prawej komory (S'TV, systolic myocardial velocity-tricuspid valve). Prędkość skurczowa pierścienia trójdzielnego jest dobrym parametrem prognostycznym u chorych z HF zarówno w czasie rytmu zatokowego [4], jak i podczas migotania przedsionków [29]. Biegalski i wsp. [30] wykazali, że niska maksymalna skurczowa prędkość ruchu pierścienia zastawki trójdzielnej (S'TV) była najsilniejszym negatywnym czynnikiem rokowniczym u pacjentów z HF przy śmiertelności rocznej 11,9\%. Meluzín i wsp. [31] wskazali na wartość S'TV równą 10,8cm/s, poniżej której 
Tabela 2. Średnie wartości parametrów echokardiograficznych na początku badania własnego w grupie pacjentów bez incydentów $(n=23)$ i ze złożonym punktem końcowym podczas rocznej obserwacji $(n=23)$

\begin{tabular}{|c|c|c|c|}
\hline $\begin{array}{l}\text { Parametry } \\
\text { echokardiogra- } \\
\text { ficzne }\end{array}$ & $\begin{array}{l}\text { Grupa pacjen- } \\
\text { tów bez incy- } \\
\text { dentów }\end{array}$ & $\begin{array}{l}\text { Grupa pacjen- } \\
\text { tów ze złożo- } \\
\text { nym punktem } \\
\text { końcowym }\end{array}$ & $p$ \\
\hline Proste & $\begin{array}{c}\text { Średnia } \pm \\
\text { odchylenie } \\
\text { standardowe }\end{array}$ & $\begin{array}{c}\text { Średnia } \pm \\
\text { odchylenie } \\
\text { standardowe }\end{array}$ & \\
\hline LVDd [cm] & $7,5 \pm 1,0$ & $7,2 \pm 0,7$ & 0,3187 \\
\hline LVDs [cm] & $6,6 \pm 1,2$ & $6,4 \pm 0,7$ & 0,5975 \\
\hline $\mathrm{LA}[\mathrm{cm}]$ & $5,1 \pm 0,9$ & $5,3 \pm 0,7$ & 0,3805 \\
\hline EF (\%) & $22,7 \pm 5,3$ & $22,7 \pm 5,1$ & 0,9774 \\
\hline $\mathrm{RVD}[\mathrm{cm}]$ & $3,1 \pm 0,7$ & $3,7 \pm 0,7$ & 0,0068 \\
\hline $\mathrm{RA}[\mathrm{cm}]$ & $4,6 \pm 0,9$ & $5,2 \pm 0,9$ & 0,0144 \\
\hline IVCexp [mm] & $18,6 \pm 5,5$ & $22,6 \pm 7,8$ & 0,0532 \\
\hline IVCinsp [mm] & $11,6 \pm 5,9$ & $18,8 \pm 7,0$ & 0,0005 \\
\hline TAPSE [mm] & $18,6 \pm 5,9$ & $15,1 \pm 4,7$ & 0,0320 \\
\hline $\mathrm{S}^{\prime} \mathrm{TV}[\mathrm{cm} / \mathrm{s}]$ & $7,87 \pm 2,65$ & $6,10 \pm 2,37$ & 0,0206 \\
\hline RVSP [mm Hg] & $39,4 \pm 13,7$ * & $45,9 \pm 13,5$ & 0,1919 \\
\hline $\begin{array}{l}\text { RVSPskor } \\
\text { [mm Hg] }\end{array}$ & $32,5 \pm 12,1$ & $45,0 \pm 13,9$ & 0,0022 \\
\hline \multicolumn{4}{|l|}{ Złożone } \\
\hline IVC\% & $40,4 \pm 17,8$ & $21,7 \pm 14,7$ & 0,0003 \\
\hline RVD/TAPSE & $0,18 \pm 0,08$ & $0,26 \pm 0,09$ & 0,0024 \\
\hline RA/TAPSE & $0,27 \pm 0,10$ & $0,38 \pm 0,13$ & 0,0026 \\
\hline RA/S'TV & $0,64 \pm 0,26$ & $0,98 \pm 0,37$ & 0,0008 \\
\hline IVCinsp/TAPSE & $0,71 \pm 0,46$ & $1,36 \pm 0,65$ & 0,0003 \\
\hline IVCinsp/S'TV & $1,65 \pm 1,00$ & $3,51 \pm 1,70$ & 0,0000 \\
\hline IVC\%*TAPSE & $743^{*}$ & $327 *$ & 0,0002 \\
\hline IVC\%*S'TV & $4946 *$ & $2163 *$ & 0,0003 \\
\hline $\begin{array}{l}\text { RA*IVCinsp/ } \\
\text { /S'TV }\end{array}$ & $7,76 \pm 5,35$ & $\begin{array}{c}18,84 \\
\pm 10,02\end{array}$ & 0,0000 \\
\hline $\begin{array}{l}\text { RVSPskor/ } \\
\text { /TAPSE }\end{array}$ & $1,78^{*}$ & 3,07 * & 0,0005 \\
\hline
\end{tabular}

istotnie częściej obserwowano zwiększoną śmiertelność, konieczność hospitalizacji z powodu CHF lub wszczepienia ICD. W badaniu Damy i wsp. wskazano na przewagę parametru S'TV nad wynikami echokardiografii klasycznej, w tym TAPSE i FAC. W analizie wieloczynnikowej prędkość S'TV z progową wartością równą $9,5 \mathrm{~cm} / \mathrm{s}$, wraz z klasą według NYHA i stężeniem peptydu natriuretycznego typu B (BNP, B-type natriuretic peptide), stanowiła niezależny czynnik ryzyka złożonego punktu końcowego [20].W grupie chorych z HF i migotaniem przedsionków maksymalna prędkość pierścienia trójdzielnego poniżej $9,0 \mathrm{~cm} / \mathrm{s}$ okazała się również dobrym czynnikiem rokowniczym [29].

Prawy przedsionek (RA, right atrium) jest rzadko przedmiotem badań u chorych z HF. Wyniki badania Hinderlitera i wsp. dotyczącego analizy czynników rokowniczych u chorych z ciężką skurczową HF dowodzą, że to błąd [19]. Spośród licznych parametrów echokardiograficznych wartość pola powierzchni prawego przedsionka okazała się najlepszym prognostykiem zarówno w analizie przeżycia jedno-, jak i wieloczynnikowej. W badaniu Neuholda i wsp. [32] u chorych z HF i niedomykalnością zastawki trójdzielnej wykazano w analizie jednoczynnikowej, że zarówno obecność dużej fali zwrotnej mitralnej, jak i wymiar prawego przedsionka miały wpływ na rokowanie. Ku zaskoczeniu badaczy w analizie wieloczynnikowej, poza EF, stężeniem N-końcowego fragmentu propeptydu natriuretycznego typu B (NT-proBNP, N-terminal B-type natriuretic propeptide), ciśnieniem skurczowym i klasa NYHA to właśnie wymiar RA, a nie obecność niedomykalności mitralnej, determinował osiągnięcie złożonego punktu końcowego, jakim było przeszczepienie serca, implantacja LVAD lub zgon [32].

Średnicę żyły głównej dolnej (IVC, interior vena cava) i jej zmienność oddechową stosunkowo łatwo mierzy się u większości pacjentów w projekcji podmostkowej w prezentacji M. Udowodniono, że parametry te są czynnikiem rokowniczym niezależnie od wartości skurczowego ciśnienia tętniczego oraz LVEF [21], przewyższając pod względem swoistości i czułości prognostyczną wartość wielkości pola lewego przedsionka, maksymalnego gradientu fali zwrotnej przez zastawkę trójdzielną i TAPSE. Co ciekawe, w analizie dużego badania Natha i wsp. [33], obejmującego ponad 3700 badań echokardiograficznych u ludzi bez określonego wywiadu chorobowego, poszerzenie i brak zapadania się oddechowego IVC było niezależnym czynnikiem rokowniczym śmiertelności z każdej przyczyny (HR [hazard ratio] 1,43).

W badaniu własnym zarówno wymiar RV, RA żyły głównej dolnej, jak i wykładniki funkcji skurczowej RV (TAPSE i S'TV), w odróżnieniu od parametrów dotyczących lewego serca, okazały się dobrymi parametrami prognostycznymi u chorych z ciężką skurczową HF (tab. 2).

Pacjenci z rozpoznaną skurczową HF i nadciśnieniem płucnym są obarczeni większą śmiertelnością niż chorzy bez tego powikłania [34]. W historycznym już badaniu z 1984 roku Yock i wsp. [35] udowodnili, że maksymalny gradient uzyskiwany z prędkości fali zwrotnej trójdzielnej bardzo dobrze koreluje (współczynnik korelacji $r=0,93$ ) z wartościami skurczowego ciśnienia w tętnicy płucnej mierzonego inwazyjnie. Kjaergaard i wsp., badając chorych z zachowana, jak i obniżoną LVEF, wykazali, że każdy wzrost ciśnienia skurczowego w prawej komorze $05 \mathrm{~mm}$ Hg zwiększa śmiertelność o 9\% w ciągu 5,5-letniej obser- 
wacji, bez względu na wiek i obecność choroby płuc [22]. Praktycznym ograniczeniem wykorzystania RVSP okazuje się nieobecność fali zwrotnej trójdzielnej w ponad 25\% przypadków [36]. W badaniu własnym dopiero uwzględnienie wartości referencyjnej (25 mm Hg) w przypadku braku wyniku pomiaru ujawniło wartość prognostyczną tego parametru (RVSPskor).

W ostatnich latach opublikowano kilka doniesień dotyczących łącznego wpływu parametrów związanych z funkcją RV oraz ciśnieniem w tętnicy płucnej. Rewolucyjnym opracowaniem, które zmieniło pogląd na znaczenie nadciśnienia płucnego i dysfunkcji RV w rokowaniu pacjentów z ciężką HF, było badanie Ghio i wsp. z 2001 roku [37]. Badacze ci u 377 chorych kwalifikowanych do przeszczepu serca z powodu ciężkiej skurczowej HF (EF < 35\%) wykonali cewnikowanie prawego serca, za pomocą którego oznaczyli ciśnienie w tętnicy płucnej i RVEF. Zaskakującym był fakt, że chociaż dla całej grupy badanej obydwa te parametry wnosiły niezależne informacje prognostyczne, to w określonych podgrupach jako pojedyncze nie miały wartości diagnostycznej. Chorzy z nadciśnieniem płucnym bez upośledzenia funkcji skurczowej RV oraz pacjenci z obniżoną RVEF bez nadciśnienia płucnego nie rokowali gorzej od chorych, u których obydwa te parametry były prawidłowe. Od tego czasu skonstruowano wiele badań mających na celu znalezienie podobnych zależności w sposób nieinwazyjny. W badaniu z 2010 roku Adhyapak [38] analogicznie do Ghio i wsp. podzielił grupę badaną na 4 podgrupy w zależności od obecności nadciśnienia płucnego i dysfunkcji RV. W tym celu wykorzystał znane parametry echokardiograficzne: RVSP i S'TV. Podobnie jak w badaniu Ghio i wsp., grupa z współistniejącym wysokim ciśnieniem skurczowym w tętnicy płucnej i dysfunkcją skurczową RV rokowała najgorzej, osiągając prawie 9-procentową śmiertelność w ciągu około roku. Biorąc jednakże pod uwage liczbę przypadków zaostrzenia HF, również chorzy w podgrupie z nadciśnieniem płucnym i zachowa- ną czynnością skurczową RV różnili się istotnie od osób w grupie z prawidłowym ciśnieniem w tętnicy płucnej. W nowszym badaniu Ghio i wsp. [39], uwzględniającym dane echokardiograficzne, określono punkty odcięcia dla TAPSE ( $\leq 14 \mathrm{~mm}$ ) oraz RVSP ( $\geq 40 \mathrm{~mm} \mathrm{Hg}$ ), których współistnienie determinowało złe rokowanie. Niska wartość TAPSE przy braku nadciśnienia płucnego nie wpływała na gorsze rokowanie [39]. Guazzi i wsp. [23] opracowali parametr, będący ilorazem TAPSE i RVSP, którego wartość progowa $0,36 \mathrm{~mm} / \mathrm{mm} \mathrm{Hg}$ dobrze prognozowała wystąpienie złożonego punktu końcowego.

Na podstawie tych opracowań w badaniu własnym przeprowadzono analizę statystyczną łączonych parametrów w zestawieniach: funkcja RV-jej obciążenie objętościowe/ /ciśnieniowe (tab. 2). Określenie punktów odcięcia na podstawie krzywych (ROC, receiver operating characteristics curve) i wykreślenie krzywych przeżycia Kaplana-Meiera udowodniło ich przewage nad parametrami prostymi. Dokładność diagnostyczna (łączne uwzględnienie czułości i swoistości) parametru złożonego RA*IVCinsp/S'TV równała się dokładności parametrów uzyskiwanych podczas cewnikowania prawego serca.

\section{Wnioski}

Niewydolność serca z obniżoną frakcją wyrzutową (EF < $<35 \%$ ) jest jednostką chorobową o poważnym rokowaniu. Badanie echokardiograficzne, poza ustaleniem rozpoznania, dostarcza wielu danych prognostycznych. Za najważniejsze uważa się parametry świadczące o podwyższonym ciśnieniu napełniania LV (E/e'), nadciśnieniu płucnym (RVSP) oraz funkcji RV (TAPSE, S'TV). Nie bez wpływu na rokowanie pozostają wymiary jam serca, a zwłaszcza niedoceniany wymiar żyły głównej dolnej i jej ruchomość oddechowa. Łączne rozpatrywanie kilku parametrów echokardiograficznych opisujących funkcję skurczową RV i nadciśnienie płucne znacznie zwiększa ich wartość prognostyczną.

\section{Abstract}

Echocardiography holds an established position in diagnosis of the heart. Giving capability of its function and structure assessment it is essential for diagnosing heart failure (HF), differential diagnosis and prognosis. Typical features of congestive HF: left ventricular dimensions end ejection fraction are used to build most common prognostic scales. Nevertheless in the patients with the most severe dysfunction of the left ventricle hemodynamic complications may have more significant prognostic value. These complications are: elevated left ventricular filling pressure and the consequent pulmonary hypertension, volume and pressure overload of the right ventricle with its systolic dysfunction. Both classic and novel echocardiography parameters prove to be useful prognostic tools in the HF with reduced ejection fraction.

Key words: echocardiography, prognosis, chronic heart failure

Folia Cardiologica 2017; 12, 4: 362-370 


\section{Piśmiennictwo}

1. Ponikowski P, Voors AA, Anker SD, et al. Authors/Task Force Members, Document Reviewers, Authors/Task Force Members. 2016 ESC Guidelines for the diagnosis and treatment of acute and chronic heart failure: The Task Force for the diagnosis and treatment of acute and chronic heart failure of the European Society of Cardiology (ESC). Developed with the special contribution of the Heart Failure Association (HFA) of the ESC. Eur Heart J. 2016; 37(27): 2129-2200, doi: 10.1093/eurheartj/ehw128, indexed in Pubmed: 27206819.

2. Bleumink GS, Knetsch AM, Sturkenboom MC, et al. Quantifying the heart failure epidemic: prevalence, incidence rate, lifetime risk and prognosis of heart failure The Rotterdam Study. Eur Heart J. 2004; 25(18): 1614-1619, doi: 10.1016/j.ehj.2004.06.038, indexed in Pubmed: 15351160.

3. Sachero A, Casazza F, Recalcati F, et al. [Clinical and prognostic significance of echocardiographic parameters in dilated cardiomyopathy: a prospective study on 225 patients. The Italian Multicenter Study of Cardiomyopathies Group]. G Ital Cardiol. 1992; 22(9): 1077-1090, indexed in Pubmed: 1291425.

4. Meluzín J, Spinarová L, Dušek L, et al. Prognostic importance of the right ventricular function assessed by Doppler tissue imaging. Eur J Echocardiogr. 2003; 4(4): 262-271, indexed in Pubmed: 14611821.

5. Levy WC, Mozaffarian D, Linker DT, et al. The Seattle Heart Failure Model: prediction of survival in heart failure. Circulation. 2006; 113(11): 1424-1433, doi: 10.1161/CIRCULATIONAHA.105.584102, indexed in Pubmed: 16534009.

6. Madsen BK, Hansen JF, Stokholm KH, et al. Chronic congestive heart failure. Description and survival of 190 consecutive patients with a diagnosis of chronic congestive heart failure based on clinical signs and symptoms. Eur Heart J. 1994; 15(3): 303-310, indexed in Pubmed: 8013501.

7. Spinar J, Vítovec J, Spac J, et al. Non-invasive prognostic factors in chronic heart failure. One-year survival of 300 patients with a diagnosis of chronic heart failure due to ischemic heart disease or dilated cardiomyopathy. Int J Cardiol. 1996; 56(3): 283-288, indexed in Pubmed: 8910074.

8. Sengeløv M, Jørgensen PG, Jensen JS, et al. Global Longitudinal Strain Is a Superior Predictor of All-Cause Mortality in Heart Failure With Reduced Ejection Fraction. JACC Cardiovasc Imaging. 2015; 8(12): 1351-1359, doi: 10.1016/j.jcmg.2015.07.013, indexed in Pubmed: 26577264.

9. Acarturk E, Koc M, Bozkurt A, et al. Left atrial size may predict exercise capacity and cardiovascular events in patients with heart failure. Tex Heart Inst J. 2008; 35(2): 136-143, indexed in Pubmed: 18612491.

10. Giannuzzi $P$, Temporelli $P$, Bosimini $E$, et al. Independent and incremental prognostic value of doppler-derived mitral deceleration time of early filling in both symptomatic and asymptomatic patients with left ventricular dysfunction. Journal of the American College of Cardiology. 1996; 28(2): 383-390, doi: 10.1016/0735-1097(96)00163-5.

11. Rossi A, Cicoira M, Bonapace S, et al. Left atrial volume provides independent and incremental information compared with exercise tolerance parameters in patients with heart failure and left ventricular systolic dysfunction. Heart. 2007; 93(11): 1420-1425, doi: 10.1136/ /hrt.2006.101261, indexed in Pubmed: 17164482.

12. Rossi D, Pinna GD, La Rovere MT, et al. Prognostic significance of tissue-Doppler imaging in chronic heart failure patients on transplant waiting list: a comparative study with right heart catheterization. Eur J Echocardiogr. 2011; 12(2): 112-119, doi: 10.1093/ejechocard/ /jeq154, indexed in Pubmed: 21036773.
13. Morales FJ, Asencio MC, Oneto J, et al. Deceleration time of early filling in patients with left ventricular systolic dysfunction: functional and prognostic independent value. Am Heart J. 2002; 143(6): 1101-1106, indexed in Pubmed: 12075269.

14. Okura $\mathrm{H}$, Takada $\mathrm{Y}$, Kubo $\mathrm{T}$, et al. Functional mitral regurgitation predicts prognosis independent of left ventricular systolic and diastolic indices in patients with ischemic heart disease. J Am Soc Echocardiogr. 2008; 21(4): 355-360, doi: 10.1016/j.echo.2007.06.002, indexed in Pubmed: 17658723.

15. Maekawa E, Inomata T, Watanabe I, et al. Prognostic significance of right ventricular dimension on acute decompensation in chronic left-sided heart failure. Int Heart J. 2011; 52(2): 119-126, indexed in Pubmed: 21483173.

16. Sun JP, James KB, Yang XS, et al. Comparison of mortality rates and progression of left ventricular dysfunction in patients with idiopathic dilated cardiomyopathy and dilated versus nondilated right ventricular cavities. Am J Cardiol. 1997; 80(12): 1583-1587, indexed in Pubmed: 9416940.

17. Ghio S, Recusani F, Klersy C, et al. Prognostic usefulness of the tricuspid annular plane systolic excursion in patients with congestive heart failure secondary to idiopathic or ischemic dilated cardiomyopathy. Am J Cardiol. 2000; 85(7): 837-842, indexed in Pubmed: 10758923.

18. Vizzardi E, D’Aloia A, Bordonali T, et al. Long-term prognostic value of the right ventricular myocardial performance index compared to other indexes of right ventricular function in patients with moderate chronic heart failure. Echocardiography. 2012; 29(7): 773-778, doi: 10.1111/j.1540-8175.2012.01703.x, indexed in Pubmed: 22494097.

19. Hinderliter AL, Blumenthal JA, O'Conner C, et al. Independent prognostic value of echocardiography and $\mathrm{N}$-terminal pro-B-type natriuretic peptide in patients with heart failure. Am Heart J. 2008; 156(6): 1191-1195, doi: 10.1016/j.ahj.2008.07.022, indexed in Pubmed: 19033018.

20. Damy T, Viallet C, Lairez 0 , et al. Comparison of four right ventricular systolic echocardiographic parameters to predict adverse outcomes in chronic heart failure. Eur J Heart Fail. 2009; 11(9): 818-824, doi: 10.1093/eurjhf/hfp111, indexed in Pubmed: 19696055.

21. Pellicori P, Carubelli V, Zhang J, et al. IVC diameter in patients with chronic heart failure: relationships and prognostic significance. JACC Cardiovasc Imaging. 2013; 6(1): 16-28, doi: 10.1016/j. jcmg.2012.08.012, indexed in Pubmed: 23328557.

22. Kjaergaard J, Akkan D, Iversen $\mathrm{K}$, et al. Prognostic Importance of Pulmonary Hypertension in Patients With Heart Failure. The American Journal of Cardiology. 2007; 99(8): 1146-1150, doi: 10.1016/j.amjcard.2006.11.052.

23. Guazzi M, Bandera F, Pelissero G, et al. Tricuspid annular plane systolic excursion and pulmonary arterial systolic pressure relationship in heart failure: an index of right ventricular contractile function and prognosis. Am J Physiol Heart Circ Physiol. 2013; 305(9): H1373-H1381, doi: 10.1152/ajpheart.00157.2013, indexed in Pubmed: 23997100.

24. Dini FL, Capozza P, Donati F, et al. Patterns of left ventricular remodeling in chronic heart failure: prevalence and prognostic implications. Am Heart J. 2011; 161(6): 1088-1095, doi: 10.1016/ /j.ahj.2011.03.027, indexed in Pubmed: 21641355.

25. Gilewski W. Wartość diagnostyczna i rokownicza nieinwazyjnych i inwazyjnych parametrów hemodynamicznych u chorych z ciężką skurczową niewydolnością serca podczas rocznej obserwacji. (niepublikowana rozprawa doktorska) Collegium Medicum im. Ludwika Rydygiera 
w Bydgoszczy, Uniwersytet Mikołaja Kopernika w Toruniu. (sygnatura czyt. 66186).

26. Correale M, Totaro A, leva R, et al. Tissue Doppler imaging in coronary artery diseases and heart failure. Curr Cardiol Rev. 2012; 8(1): 43-53, indexed in Pubmed: 22845815.

27. Lang RM, Badano LP. Mor-AviV.iwsp. Recommendations for cardiac chamber quantification by echocardiography in adults: an up-date from the American Society of Echocardiography and the European Association of Cardiovascular Imaging. Eur Heart J Cardiovasc Imaging. 2015; 16: 233-271.

28. Kaul S, Tei C, Hopkins JM, et al. Assessment of right ventricular function using two-dimensional echocardiography. Am Heart J. 1984; 107(3): 526-531, indexed in Pubmed: 6695697.

29. Kim H, Jung $\mathrm{C}$, Yoon $\mathrm{HJ}$, et al. Prognostic value of tricuspid annular tissue Doppler velocity in heart failure with atrial fibrillation. J Am Soc Echocardiogr. 2012; 25(4): 436-443, doi: 10.1016/j. echo.2011.12.019, indexed in Pubmed: 22245051.

30. Biegalski W, Poprawski K. Kandziora M. i wsp.: Prognostic value of left and right ventricular dysfunction in heart failure patients. Eur J Echocardiography. 2006; 7: 107.

31. Meluzín J. Pulsed Doppler tissue imaging of the velocity of tricuspid annular systolic motion. A new, rapid, and non-invasive method of evaluating right ventricular systolic function. Eur Heart J 2001; 22(4): 340-348, doi: 10.1053/euhj.2000.2296.

32. Neuhold S, Huelsmann M, Pernicka E, et al. Impact of tricuspid regurgitation on survival in patients with chronic heart failure: unexpected findings of a long-term observational study. Eur Heart J. 2013; 34(11): 844-852, doi: 10.1093/eurheartj/ehs465, indexed in Pubmed: 23335604.
33. Nath J, Vacek JL, Heidenreich PA. A dilated inferior vena cava is a marker of poor survival. Am Heart J. 2006; 151(3): 730-735, doi: 10.1016/j.ahj.2005.04.023, indexed in Pubmed: 16504642.

34. Cappola TP. Pulmonary Hypertension and Risk of Death in Cardiomyopathy: Patients With Myocarditis Are at Higher Risk. Circulation. 2002; 105(14): 1663-1668, doi: 10.1161/01.cir.0000013771.30198.82.

35. Yock PG, Popp RL. Noninvasive estimation of right ventricular systolic pressure by Doppler ultrasound in patients with tricuspid regurgitation. Circulation. 1984; 70(4): 657-662, indexed in Pubmed: 6478568.

36. Yared K, Noseworthy P, Weyman AE, et al. Pulmonary artery acceleration time provides an accurate estimate of systolic pulmonary arterial pressure during transthoracic echocardiography. J Am Soc Echocardiogr. 2011; 24(6): 687-692, doi: 10.1016/j.echo.2011.03.008, indexed in Pubmed: 21511434.

37. Ghio S, Gavazzi A, Campana C, et al. Independent and additive prognostic value of right ventricular systolic function and pulmonary artery pressure in patients with chronic heart failure. J Am Coll Cardiol. 2001; 37(1): 183-188, indexed in Pubmed: 11153735.

38. Adhyapak SM. Effect of right ventricular function and pulmonary pressures on heart failure prognosis. Prev Cardiol. 2010; 13(2): $72-$ -77, doi: 10.1111/j.1751-7141.2009.00053.x, indexed in Pubmed: 20377809.

39. Ghio S, Temporelli PL, Klersy C, et al. Prognostic relevance of a non-invasive evaluation of right ventricular function and pulmonary artery pressure in patients with chronic heart failure. Eur J Heart Fail. 2013; 15(4): 408-414, doi: 10.1093/eurjhf/hfs208, indexed in Pubmed: 23307814. 